This document was prepared in conjunction with work accomplished under Contract No. DE-AC09-96SR18500 with the U. S. Department of Energy.

\title{
DISCLAIMER
}

This report was prepared as an account of work sponsored by an agency of the United States Government. Neither the United States Government nor any agency thereof, nor any of their employees, nor any of their contractors, subcontractors or their employees, makes any warranty, express or implied, or assumes any legal liability or responsibility for the accuracy, completeness, or any third party's use or the results of such use of any information, apparatus, product, or process disclosed, or represents that its use would not infringe privately owned rights. Reference herein to any specific commercial product, process, or service by trade name, trademark, manufacturer, or otherwise, does not necessarily constitute or imply its endorsement, recommendation, or favoring by the United States Government or any agency thereof or its contractors or subcontractors. The views and opinions of authors expressed herein do not necessarily state or reflect those of the United States Government or any agency thereof. 
Key Words:

TPBAR

LTA

UDQE

ILV
Retention:

Permanent

\section{Impact of the Proposed Addition of 3 Un-extracted Cycle 6 TPBARs to the Lead Test Assembly}

Prepared by:

$\begin{array}{ll}\text { Robert A. Hiergesell } & \text { October, } 2005\end{array}$

Westinghouse Savannah River Company LLC

Savannah River Site

Aiken, SC 29808 


\section{DISCLAIMER}

This report was prepared for the United States Department of Energy under Contract No. DE-AC09-96SR18500 and is an account of work performed under that contract. Reference herein to any specific commercial product, process, or does not necessarily constitute or imply endorsement, recommendation, or favoring of same by Westinghouse Savannah River Company or by the United States Government or any agency thereof. The views and opinions of the authors expressed herein do not necessarily state or reflect those of the United States Government or any agency thereof.

Printed in the United States of America

Prepared For

U.S. Department of Energy 
Key Words:

TPBAR

LTA

UDQE

ILV
Retention:

Permanent

\section{Impact of the Proposed Addition of 3 Un-extracted Cycle 6 TPBARs to the Lead Test Assembly}

Prepared by:

Robert A. Hiergesell

Westinghouse Savannah River Company LLC

Savannah River Site

Aiken, SC 29808

Prepared for the U.S. Department of Energy under Contract No. DE-AC09-96SR1850 


\section{REVIEWS AND APPROVALS}

\section{Author}

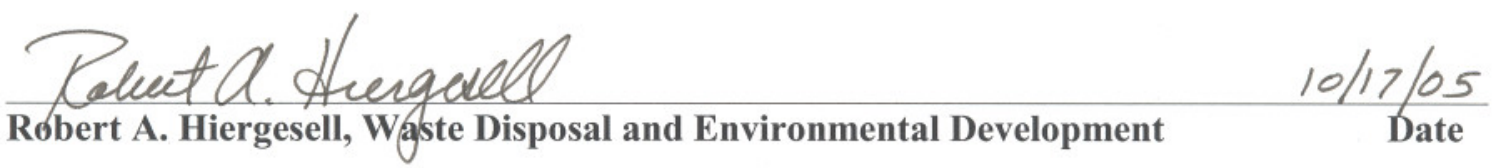

\section{SRNL Approvals/Review}

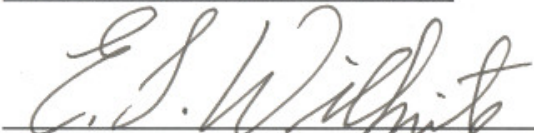

E.L. Wilhite, Reviewer, Waste Processing Technology

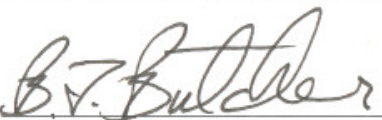

B.T. Butcher, L4 Manager, Waste Disposal and Environmental Development

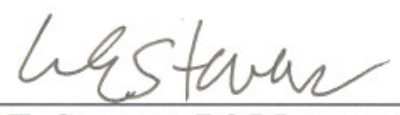

W.E. Stevens, L3 Manager, Waste Disposal and Environmental Development

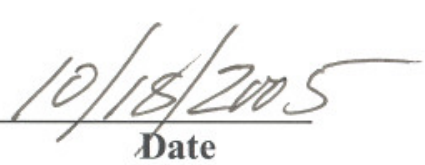

Date

Waste Management Area Project Approval

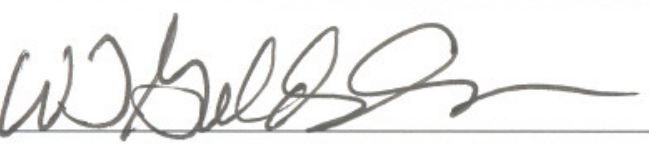

W. T. Goldston, Waste Management Area Project

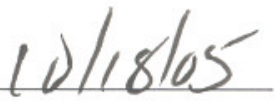

Date

L.T. Reid, Waste Management Area Project, Engineering Manager

$$
\text { Deputy }
$$

khotem

K. A. Stone, Waste Management Area Project

Solid Waste Management Facility Manager $\frac{10 / 17 / 05}{\text { Date }}$

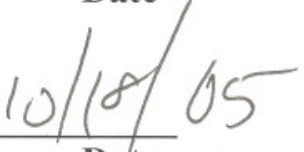

Date 
Rev. 0

\section{LIST OF ACRONYMS and ABBREVIATIONS}

TPBAR Tritium Producing Burnable Absorber Rod

ILV

LTA

Intermediate Level Vaults

SA Lead Test Assembly

UDQE

Special Analysis

Unreviewed Disposal Question Evaluation 
Rev. 0

This Page Intentionally Left Blank 


\section{Introduction}

The Tritium Readiness Program is planning to ship three (3) additional unextracted Tritium Producing Burnable Absorber Rods (TPBARs) in the Lead Test Assembly (LTA) container to SRS for disposal. These rods are from the PIE (Post Irradiation Examination) program that is currently underway at ANL-W and will not have been extracted. The three rods were irradiated in Watts Bar Cycle 6 (irradiation was completed on February 22, 2005) after which they were sent to ANL-W for neutron radiography and gamma scanning. Once arriving at SRS, the LTA will be placed within the first TPBAR disposal container which will then be disposed within the Intermediate Level Vault (ILV). To determine the potential impact with respect to those performance measures, this UDQE addresses the proposed action to include the 3 PIE TPBARs, with an associated $2.8 \mathrm{E}+04 \mathrm{Ci}$ of tritium, within the LTA.

The first TPBAR disposal container was previously evaluated to determine its suitability for disposal within the ILV in a Special Analysis (SA), see Hiergesell and Wilhite, 2004. At the time that investigation was conducted the plan was to place 32 unextracted TPBARs containing $1.71 \mathrm{E}+05 \mathrm{Ci}$ of tritium within the LTA. In addition to this, the first TPBAR disposal container is expected to contain 900 extracted TPBARs with an associated $\sim 1.2 \mathrm{E}+05 \mathrm{Ci}$ of tritium. That study concluded that the placement of the disposal container, along with the LTA and its original contents, could be disposed within the ILV without causing any exceedance of DOE Order 435.1 performance measures. It should be noted that the 900 extracted TPBARs are a bounding case for the purposes of the SA and that the current best estimate is that only 474 extracted TPBARs will actually be placed in the container.

In Hiergesell and Wilhite, 2004, one of the major considerations in determining suitability for disposal was evaluating the release of tritium from the disposal container and its subsequent migration from the ILV into the groundwater flow system. Part of the tritium source term in that investigation was the estimated tritium permeation rate from the LTA container, which is housed within the larger TPBAR disposal container. The calculation of the LTA tritium permeation rate was documented in a separate report, Vinson, et. al., 2004. The calculation was conservative and provided a worst-case, steady-state rate of $24 \mathrm{Ci} /$ year.

\section{Evaluation}

To evaluate the question of whether the proposed addition of 3 unextracted TPBARs will have a significant impact on the suitability of disposing the initial TPBAR container within the ILV, a new calculation of the rate of tritium permeation through the LTA walls was conducted and is documented in Clark, 2005. The new analysis took into account the added 2.81E+04 Ci of tritium associated with 3 unextracted TPBARs (see email from Brizes to Hiergesell in the Appendix) as well as changes in the design features of the LTA that were proposed after the initial tritium permeation rate calculation. The increase from the previous LTA total of $1.71 \mathrm{E}+05 \mathrm{Ci}$ to a new LTA total of 225,253 Ci, represents a 16.4 percent increase in the LTA tritium inventory. The increase of $2.8 \mathrm{E}+04 \mathrm{Ci}$ represents only a 9.6 percent increase of the overall TPBAR disposal container inventory.

The LTA design change is reflected in the latest engineering drawings, INL PRO/E Drawing Number W0024-1750-ED-01, Sheet 2 of 3 and primarily involves switching from a box-shaped container to a cylindrically shaped container. 
The new tritium permeation calculation indicates that despite the increase in tritium activity within the LTA, the worst-case, steady-state diffusion rate will be $15 \mathrm{Ci} /$ year versus the originally calculated $24 \mathrm{Ci} / \mathrm{yr}$. The reduction is attributed to the reduction in overall surface area of the new LTA container through which tritium can diffuse.

In addition to tritium, the 3 PIE TPBARs were handled in the ANL-W hot cell and it is assumed that they acquired a small quantity of surface contamination of other radionuclides. This issue was addressed in Hiergesell and Wilhite, 2004, and smear data from the hot cells (at PNNL and ANL-W) were used to estimate the bounding limit of contamination that might have been transferred to the TPBARs and the shrouds that they were held within. Since the 3 additional TPBARs were evaluated at ANL-W, the smear data from that hot cell were again utilized to estimate the bounding limit of any additional surface contamination that might have been acquired during testing. Using the same method of analysis as before and assuming that the 3 TPBARs were contained within several shrouds that will also be placed within the LTA, an estimate of the additional surface contamination was made. The maximum increase for any of the radionuclides was found to be $\sim 1.1$ percent more than was determined in Hiergesell and Wilhite, 2004. Considering that none of these radionuclides will escape the TPBAR disposal container during the 1000-year PA period of performance the slight increase in inventory of these radionuclides will have no impact on the suitability for disposing the TPBAR disposal container within the ILV.

\section{$\underline{\text { Results }}$}

The new LTA tritium permeation rate of $15 \mathrm{Ci} / \mathrm{yr}$ (Clark, 2005) is less than the permeation rate utilized to determine the overall suitability of disposing the first TPBAR container within the ILV (Hiergesell and Wilhite, 2004). That Special Analysis concluded that the higher LTA tritium permeation rate, $24 \mathrm{Ci} / \mathrm{yr}$, was inconsequential to the disposal suitability of the container. Therefore, since the higher LTA tritium permeation rate was found to be inconsequential with respect to disposal of the TPBAR disposal container, it is logical to conclude that the new, lower, tritium permeation rate is also inconsequential.

To complete this UDQE, the following questions, which must be addressed in any UDQE, are answered with respect to the proposed addition of 3 unextracted TPBARS to the LTA:

a. Is the proposed activity or new information outside the bounds of the approved PA/CA (e.g., does the proposed activity or new information involve a change to the basic disposal concept as described in the PA/CA such as critical inputs/assumptions or an increase in inventory analyzed in the CA)?

No. This activity is bounded by the approved PA/CA and does not involve any changes to the basic disposal concept of placing the TPBAR container within the ILV.

b. Does the proposed activity or new information cause the PA/CA performance measures to be exceeded?

No. The DOE Order 435.1 performance measures are not exceeded by the proposed action of adding 3 additional unextracted TPBARs to the LTA. 
c. Would the radionuclide disposal limits in the approved PA need to be changed to implement the proposed activity?

No. While this UDQE addresses a small increase in tritium inventory $(\sim 1.71 \mathrm{E}+05 \mathrm{Ci}$ to $\sim 2.25 \mathrm{E}+5 \mathrm{Ci}$ ) and a very small increase in the inventory of other surface contamination radionuclides, the new design changes to the LTA container reduce the surface area through which tritium may diffuse such that the estimate of the permeation rate is lower than was previously calculated in the disposal authorizing SA. The fact that there is a very small increase ( 1.1 percent) in non-tritium radionuclides is inconsequential since they will not escape either the LTA or TPBAR disposal container within the PA period of compliance.

d. Does the new information involve a change in the radionuclide disposal limits in the approved $P A$ ?

No. The new information about the geometric shape of the LTA container has the effect of reducing the estimated permeation rate of tritium through the LTA walls, thus no change to radionuclide disposal limits are needed.

e. $\quad$ Does the proposed activity or new information involve a change to the DAS?

No. Since neither the basic disposal concept nor disposal limits are changed from that evaluated in the SA and CA, the Disposal Authorization Statement will not be changed as a result of this proposed activity.

\section{CONCLUSION}

The proposed action of adding the $2.81 \mathrm{E}+04 \mathrm{Ci}$ of tritium associated with 3 additional un-extracted TPBARs to the LTA can be accomplished without exceeding the previously estimated impact of placing the LTA within the first TPBAR disposal container. The miniscule increase in non-tritium radionuclides is inconsequential since the TPBAR disposal container effectively isolates the radionuclide contents over the PA period of compliance such that they cannot migrate away from the ILV. 


\section{REFERENCES}

Clark, E.A., 2005. Revised Estimate of Tritium Permeation Rate out of LTA Container, SRNL-MTS2005-20036, Savannah River National Laboratory, WSRC, Aiken, SC, 29808.

Email correspondence from William Brizes to Robert Hiergesell dated 9/07/05, Clarification to Memo "Re: Additional TPBARs in LTA Container"

Hiergesell, R.A., and E.L. Wilhite, 2004. Special Analysis: Evaluation of the Proposed Disposal of the Initial TEF-TPBAR Waste Container within the E-Area Low-Level Waste Facility Intermediate Level Vault. WSRC-TR-2004-00498, Rev. 0. Westinghouse Savannah River Company, Aiken, SC 29808.

INL PRO/E Drawing Number W0024-1750-ED-01, Sheet 2 of 3.

Vinson, D.W., K.H. Subramanian, and E.L. Clark, 2004. Containment Materials Performance for TPBAR Disposal, WSRC-TR-2004-00374, Westinghouse Savannah River Company, Aiken, SC, 29808. 
WSRC-RP-2005-01788

Rev. 0

\section{APPENDIX}

\section{Email from Brizes to Hiergesell:}

william Brizes/WSRCISrs

09/07/2005 09:44 AM

\author{
To Robert HiergeselliSRNUSrs@Srs, Tom Butcher/SRNUSrs@Srs \\ bobby-d.smith@srs.gov, Catherine Flavin/BSRIISrs@Srs, Elmer \\ Subject Clarification to Memo "Re: Additional TPBARs in LTA Container"
}

Bob, 240 TPBARs were irradiated in Watts Bar Cycle 6 .

* 215 TPBARs have been sent to SRS and are being stored in LWT Cask 8 .

* 19 TPBARs will be sent to SRS in October 2005 and will be stored in LWT Cask 6

* 3 TPBARs were sent to PNNL for PIE.

* 3 TPBARs were sent to ANL-W for neutron radiography and gamma scanning.

TOTAL 240 TPBARs

The 3 TPBARs that were sent to ANL-W will be included in the LTA TPBAR shipment that will be made to SRS. (September 2006 to October 2007) The three rods will be cut into four foot lengths and will not be extracted. PNNL will handle their 3 TPBARs.

The Cycle 6 irradiation was completed February 22, 2005. Each rod contained 0.974 grams of tritium at the time the reactor was shut down.

We have submitted a Draft of the FY06 AOP. However, will additional funding be required in FY06 to support the inclusion of three additional TPBARs in the LTA TPBAR shipment? Is the analysis of the 32 LTA TPBARs bounding/conservative enough to include the 3 PIE rods from Cycle 6 ? 
Rev. 0

This Page Intentionally Left Blank 


\section{Distribution:}

J. C. Griffin

773-A, Rm. A231

W. E. Stevens

773-A, Rm. A230

B. T. Butcher

773-43A, Rm. 216

J. R. Cook

773-43A, Rm. 209

R. Hiergesell

773-43A, Rm. 251

E. L. Wilhite

773-43A, Rm. 214

C.A. Flavin

233-34H, Rm. 8

W.F. Brizes

233-34H, Rm. 14

L. T. Reid

705-3C, Rm. 115

D. F. Sink

724-15E, Rm. 2

K. L. Tempel

724-15E, Rm. 4

W. T. Goldston

705-3C, Rm. 105

K. A. Stone

724-7E, Rm. 101

E. A. Clark

773-A, Rm. C-133

STI

703-43A

WPT File

773-43A, Rm. 213

SW Document Control 642-E 